\title{
ЦАХИЛДАГНЫ ТӨРЛИЙН УРГАМЛЫН ФИЛОГЕНЕТИК ХОЛБОО
}

\author{
Х.Алтанзул, Ю.Оюунбилэг
}

Ерөнхий болон сорильн биологийн хүрээлэнгийн Ургамльн биотехнологийн лаборатори, Шинжлэх ухааны Академи, Монгол улс Цахим шуудан: altanzul.mn@gmail.com,yungeree@gmail.com

\section{ОРШИЛ}

Ургамлын ангилалзүйн судалгаа олон жилийн түүхтэй ч овог, төрөл, зүйлийн филогенетикийн хувьд ч шийдвэрлэгдээгүй асуудлууд байсаар байна.

Өнөө үед ургамлын гарал үүсэл, удам төрлийн холбоог тогтооход ихэд анхаарч молекулын түвшний судалгаа эрчимтэй хийгдсэний дүнд филогенетик системийг шинэчлэн гаргах болсон. Ангиллын энэхүҮ систем нь ургамлын эсийн бөөм, митохондрийн болон хлоропластын ДНХийн дараалалд үндэслэгдсэн тул олон судлаач зүй ёсоор хүлээн зөвшөөрдөг.

Манай оронд сүүлийн үед цөөн тооны судлаачид зарим ургамлын ангилалзүйн судалгааг молекулын түвшинд гадаад оронд хийсэн ажлуудаас өөр хийгдээгүй, харьцангуй бага судлагдсан зэргээс дүгнэлт хийж зарим эмийн ач холбогдолтой ургамалын ангилалзүйн судалгаанд энэхүҮ аргыг хэрэглэх шаардлагатай гэж үзсэн болно.

Цахилдагны зүйл ургамлууд нь Цахилдагтаны (Iridaceae) овгийн нэлээд том, их ярвигтай төрөлд хамаардаг. Төрлийн нэр нь грек үгээр “rainbow” (солонго) гэсэн утгатай. Мезофит, ксерофит, гидрофит гэх мэт байгалийн олон янзын ялгаатай орчинд ургадаг, тэнд дасан зохицож ургах шинж чанар нь филогенетик холбоо, эволюци хөгжлийн түүхийг судлахад хүргэдэг.

Монгол орны ургамлын аймагт 15 [1] болон 12 [2] зүйл цахилдагийг бүртгэсэн байсан бол Ургамал нарынхаар 20-иод зүйлийн цахилдаг тэмдэглэсэн [3].

Эрдэмтэн судлаач Лхагвасүрэн цахилдагийн төрлийн ургамлын хлоропластын ДНХ-ийн дарааллыг тогтоож, дэлхийн генийн санг (DDBJ) баяжуулсан ба зарим эмийн ургамлын хлоропластын ДНХ дарааллаар удам төрлийн холбоог тогтоосон $[4,5]$.

Мөн Лхагвасүрэн нарын судалгаагаар Цахилдагийн зүйл ургамлуудыг бактерийн гаралтай өвчин, хавдар, үрэвсэлт өвчнүүдийг эмчлэхэд өргөн хэрэглэж байгаа, ДНХ-ийн ойролцоо дараалалтай зүйлүүд нь ижил төсөөтэй эмийн ач холбогдолтой нэгдэл агуулдаг [6] талаар дурьдахын зэрэгцээ, эдгээр зүйл ургамлын молекул ангилалзүйг ашиглан морфологи шинж болон эмийн гаралтай бодисын гарцыг тодорхойлж, пластидийн ДНХ дарааллыг ургамал газарзүйн тархалттай нь холбон үзүүлсэн байдаг.

Бид бүхэн энэхүү судалгааны ажлыг цахилдагийн овгийн эмийн ургамлын ангилалзүйг молекулын түвшинд тогтоох нь ботаникч, ангилалзүйчдийн зарим маргаантай асуудлыг шийдвэрлэхэд дөхөм 
болох, залуу судлаачид, оюутнуудад молекул биологийн шинэлэг арга зүйг

\section{СУДАЛГААНЫ АРГАЧЛАЛ}

\section{Ургамлын материал}

Бид цахилдагны 8 зүйл ургамлын навч, навчны суурийг энэхүу судалгаандаа дээж болгон ашиглав. Үүнээс Нарийн навчит цахилдаг (Iris tenuifolia Pall.)-н дээжийг ШУА-ийн Ерөнхий болон сорилын биологийн хүрээлэнгийн Ургамлын биотехнологийн лабораторид in vitro нөхцөлд соёолуулсан 2 долоо хоногтой цухуйцаас [7], харин Цагаалин цахилдаг (I.lactea Pall.), Бунгийн цахилдаг (I.bungei Maxim.), (I.kaempferi) зүйлүүдийг тус лабораторийн үрийн сангаас авч Петрийн аяганд фильтрийн цаасан дээр соёолуулж хэрэглэв. I.kaempferi нь Германд тархан ургадаг, Монголд байдаггүй зүйл боловч бид харьцуулах зорилгоор сонгон хэрэглэсэн. Харин Шар цахилдаг (I.flavisimma Pall.), Цүдгэр цахилдаг (I.ventricosa Pall.), Бар цоохор цахилдаг (I.tigrida Bge.), Ацан цахилдаг (I.dichotoma Pall.) зүйлүүдийн хатаасан дээжийг Уламжлалт анагаaх таниулах, эзэмшүүлэх зорилготой хийж гүйцэтгэсэн болно. ухаан, технологийн хүрээлэнгийн Эрдэм шинжилгээний төвөөс авч ашиглав.

\section{Ургамлын материалаас геномын} ДНХ ялгах

Ургамлын материалаас геномын ДНХ-г ХБНГУ-ын "Macherey-Nagel", БНХАУын "Tiangen" китүүдийг (цомог) ашиглан ялган харьцуулж, ДНХ-н концентрацийг “Нанодроп”-аар тодорхойлсон.

Полимеразийн гинжин урвал, гель электрофорез

Ялгаж авсан ДНХ тус бүрээс 100 нг-Г нийт 15 мкл урвалжид тооцож хийв. Полимеразийн гинжин урвал (ПГУ) явуулахад ашигласан хос праймерийн секвенс дарааллуудыг Taberlet ба бусад 1991, Makarevitch ба бусад 2003 нарын цахилдаг болон бусад зүйл ургамал дээр хийсэн судалгааны ажлын өгүүллээс авч хэрэглэв (Праймерийн талаарх мэдээллийг Хүснэгт 1-д харуулав).

ХУснэгт 1. Цахилдагийн зүйл ургамлуудад ПГУ хийхэд ашигласан праймерийн мэдээлэл

\begin{tabular}{|l|l|c|}
\hline Праймерийн нэр & \multicolumn{1}{|c|}{ Секвенс дараалал } & Секвенсийн урт /bp/ \\
\hline S-523 & AAACCAAAATTGGGATTATCCGCAAAAAATTA & 32 \\
\hline Z-1204R & CCCTAAGGGTGTCCTAAAGTTTCTCCACC & 29 \\
\hline ITS1 & TCCGTAGGTGAACCTGCGG & 19 \\
\hline ITS4 & TCCTCCGCTTATTGATATGC & 20 \\
\hline $\operatorname{trnL}$ & CGAAATCGGTAGACGCTACG & 20 \\
\hline $\operatorname{trnF}$ & ATTTGAACTGGTGACACGAG & 20 \\
\hline
\end{tabular}

ПГУ явуулах нийт 15 мкл урвалж нь 1 мкл геномын ДНХ, 0.2 мкм dNTPs, 10 мкм праймер, $1 \mathrm{U}$ Таq полимераза фермент болон 1X буфер гэсэн агууламжтай байв. ПГУ-г дараах нөхцлийн дагуу явуулсан; эхлээд нийт ДНХ-г $94^{\circ} \mathrm{C}-д \quad 4$ мин. денатурацид оруулж задалсны дараа $94^{\circ} \mathrm{C}$ - д 40 сек, $60^{\circ} \mathrm{C}$-д 30 сек, $72^{\circ} \mathrm{C}$-д 1 мин. 30 сек 25 цикл явуулсаны эцэст $72^{\circ} \mathrm{C}$-д 10 мин. байлгаж тогтворжуулалт хийсэн. ПГУ-ын бүтээгдэхүүнийг $4^{\circ} \mathrm{C}$-д хадгалж байгаад $1.0 \%$ агароз гельд $100 \mathrm{~V}$-д 15 мин гүйлгэн этидиум бромидаар угааж хэт ягаан туяаны мужид (UV)-д харав. 


\section{Нуклеотидын дарааллын анализ}

Цахилдагны зүйл ургамлуудын праймерийн секвенсийг зохиосон хлоропластын ДНХ-н нуклеотидын хэсэгчилсэн дарааллыг Биотехнологийн үндэсний төвөөс ("National Center for Biotechnology Information (NCBI)-c (www.ncbi. nlm.nih.gov/) авсан бөгөөд филогенезийн анализыг BioEdit2.1, ClustalX2, MEGA6 програмуудыг ашиглан гүйцэтгэв.

\section{СУДАЛГААНЫ ҮР ДУН}

\begin{tabular}{|c|c|}
\hline Цахилдагны & 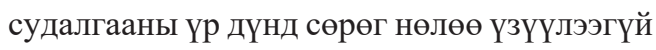 \\
\hline гамлуудаас & \\
\hline инээр соёолуулсан дээж нь хата & I.ver \\
\hline илүY хялбар байсан бөгөөд & ДНХ нь S-523, Z1204R \\
\hline әрэглэсэн хоёр китний хувьд ХБНГ & 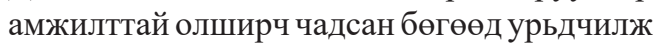 \\
\hline ит ашигласан тохиолдолд ялга & тооцсон хэмжээ болох 500-600bp-н хооро \\
\hline ошилт & "band" гарсан \\
\hline $6-1.81)$ хари & уөлд хамаарахыг б \\
\hline
\end{tabular}

\section{S-523 + Z1204R}

\section{$\begin{array}{lllllllll}M & 1 & 2 & 3 & 4 & 5 & 6 & 7 & 8\end{array}$}

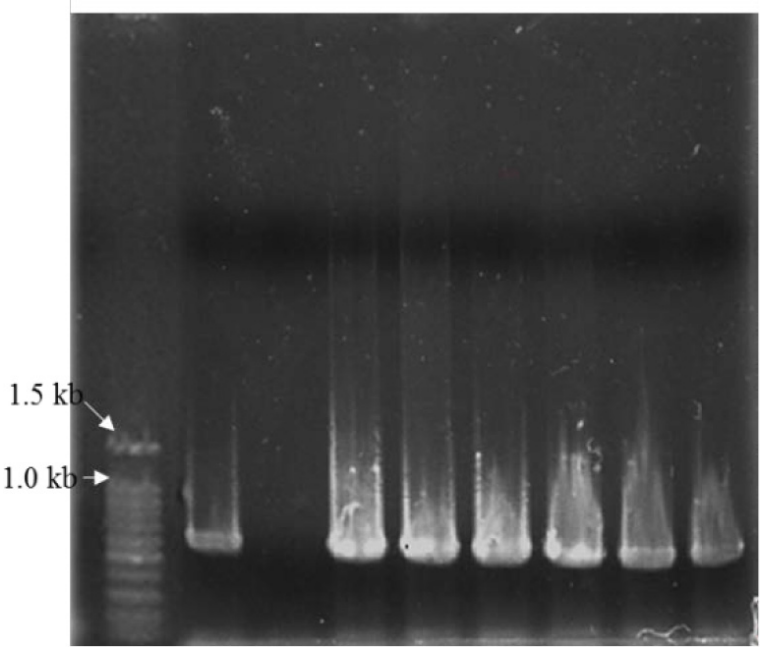

Зураг 1. S-5238, Z1204R праймеруудыг ашиглан явуулсан ПГУ-ьлн бүтээгдэхүҮний гель электрофорезийн зураг. M-DNA marker (100bp) 1. I.flavisimma 2. I.ventricosa 3. I.bungei 4. I.kaempferi 5. I.tenuifolia 6. I.lactea 7. I.tigrida 8. I.dichotoma

Internal Transcribed Spacer (ITS) нэг зүйл дотор хэд хэдэн хуулбар харуулдаг бөөмийн секвенсийг ургамлын төрөл, зүйл ба энэ нь ДНХ-н давтагдсан тодорхой хоорондын молекул филогенез холбоог дараалал байгааг илэрхийлж байгаа юм. илрүүлэхэд өргөн хэрэглэдэг. Гэсэн хэдий ч, цахилдагны зүйл ургамлуудын ITS бүс нь

ITS1, ITS4 праймеруудыг ашигласан үед 3, 4, 6-р дээж буюу I.bungei, I.kaempferi, 
I.lactea-д $1.5 \mathrm{~kb}$ болон $500 \mathrm{bp}$ тус бүрд "band" илэрсэн нь дээрх ургамлууд удам төрлийн хувьд ойролцоо байх магадлалтай ба ITS бүс нь дор хаяж 2 удаа давтагдан орсон байгааг харуулж байна. 1-р дээж буюу I.flavisimma-г 500, 600 bp-т 2 "band" илэрсэн нь удам төрлийн хувьд бусдаас ялгарах онцгой шинж байгааг илтгэх ба мөн адил ITS бүс нь дор хаяж 2 удаа давтагдан орсон байгааг харуулж байна. Харин 2, 5, 7, 8-р дээж буюу I.ventricosa, I.tenuifolia, I.tigrida, I.dichotoma-д "band" илэрсэнгүй (Зураг 2).

trnL-trnF бүс нь ургамлын хлоропластын геномд орших нэг том бүхэл хуулбар бөгөөд дотроо trnL ген, I интрон групп, trnL-F “intergenic spacer" гэсэн хэсгүүдээс тогтдог. ЭнэхүҮ ДНХ-н хэсэг дараалал дээр үндэслэн ургамлын филогенез холбоог илрүүлэхэд түгээмэл хэрэглэдэг юниверсаль праймер болох trnL, trnF-г хэрэглэхэд 2-р дээж буюу I.ventricosa-c бусад дээжний ДНХ амжилттайгаар олширч ойролцоогоор 800 bp-т “band” илэрсэн (Зураг 2) нь тэдгээр ургамлууд бүгд trnL$\operatorname{trnF}$ бүсийг бүрэн агуулсан байгааг харуулж байгаа юм. I.ventricosa дээжнээс ялгасан ДНХ-н цэвэршилт болон концентрацийг Нанодроп дээр шалгахад 260/280 үзүүлэлт 1.61, концентраци нь 120.6 нг/мкл байсан хэдий ч ПГУ бүр дээр ДНХ олширч "band” илрээгүй нь ПГУ явуулах үед алдаа гарсан байх магадлалтай юм.

\section{ITS1 + ITS4}

\section{$\operatorname{trn} L+\operatorname{trn} F$}

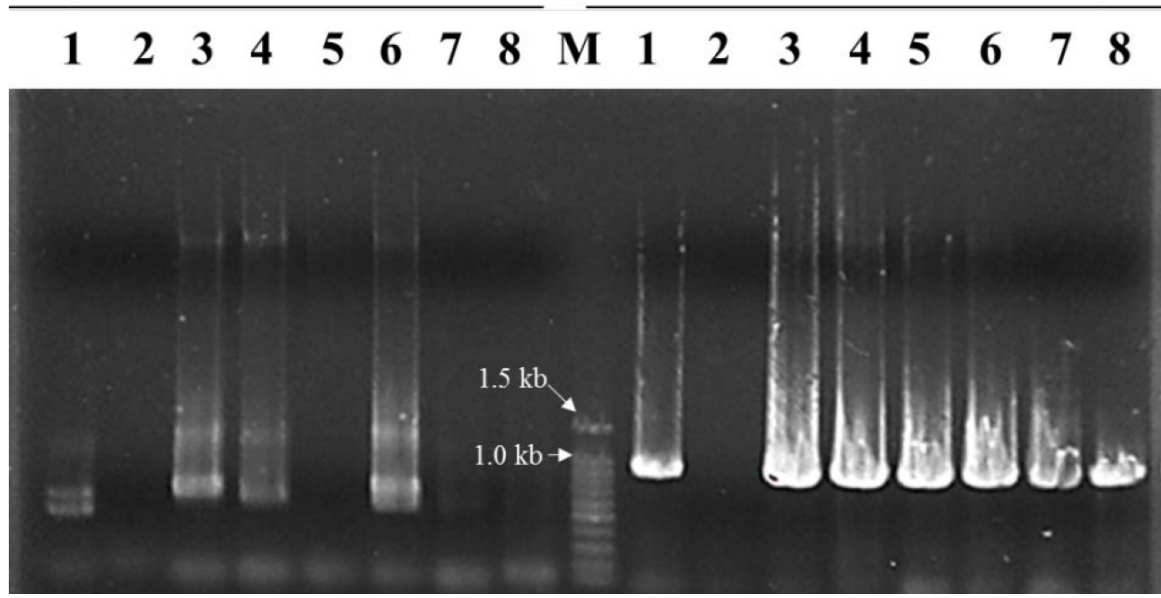

Зураг 2. ITS1, ITS4 ба trnL, trnF праймеруудыг ашиглан явуулсан ПГУ-ын бүтээгдэхүүний гель электрофорезын зураг. $M-D N A$ marker (100bp)

1. I.flavisimma 2. I.ventricosa 3. I.bungei 4. I.kaempferi 5. I.tenuifolia 6. I.lactea

7. I.tigrida 8. I.dichotoma

Цахилдагны зүйл ургамлуудын хлоропластын ДНХ-н нуклеотидын дараалал дээр үндэслэн ClustalX2, Neighbor-joining method ашиглан филогенезийн модыг байгуулав. 3-p зургаaс харахад цахилдагны зарим зүйл ургамлуудаас I.sanguinea (AF480381), I.sibirica (AF480383) удам төрлийн хувьд хамгийн ойр ба I.lactea (AF480373)-тай мөн холбогдож байгаа бол, I.rutenica (AF480380) ба I.uniflora (AF480386) филогенезийн хувьд ойролцоо болох нь харагдаж байна. Мөн I.tenuifolia (AF480384) ба I.ventricosa (AF480387) зүйлүүд удам төрлийн ойр холбоотой ба I.halophila (AF480370)тай нэг мөчирт холбогдож байна. Харин I.tigrida (AF480385) зүйл нь бусад зүйлээс хлоропластын нуклеотидын дарааллын хувьд харьцангуй хол болох нь филогенез модноос харагдаж байна. 


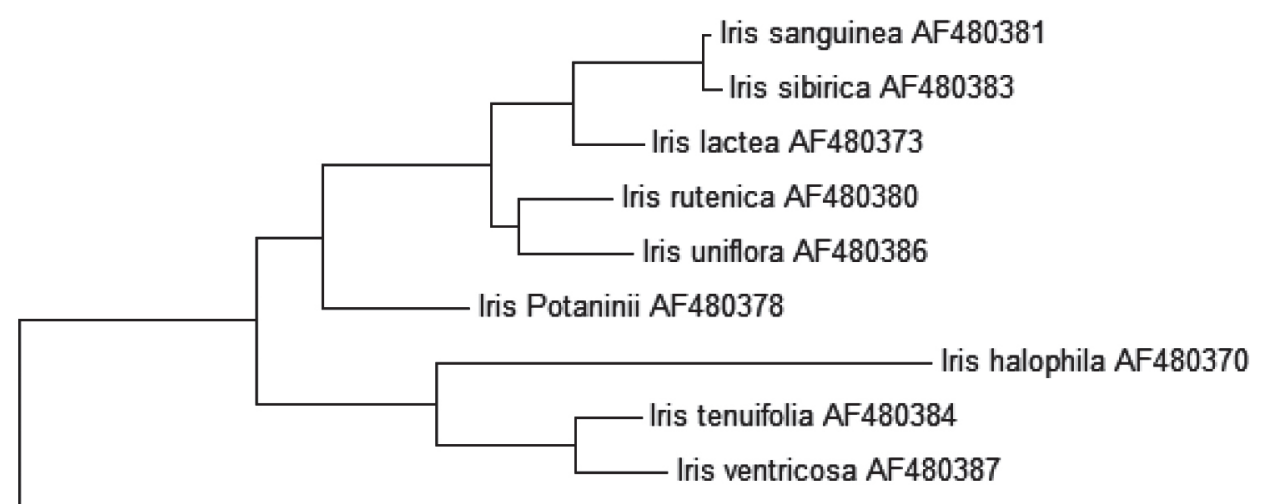

Iris tigrida AF480385

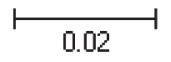

Зураг 3. Цахилдагны зарим зүйл ургамлуудын филогенезийн мод

\section{ДҮГНЭЛТ}

Цахилдагны төрлийн 7 зүйл ургамлаас ялгасан геномын ДНХ S-523, Z1204R праймеруудаар амжилттай олширч чадсан бөгөөд урьдчилж тооцсон хэмжээ болох 500-600 bр-н хооронд "band" гарсан нь дээрх зүйлүүд бүгд нэг төрөлд хамаарахыг батлан харуулж байна. ITS1, ITS4 праймеруудыг ашиглан ПГУ явуулахад I.bungei, I.kaempferi, I.lactea-д $1.5 \mathrm{~kb}$ болон 500 bp тус бүрд "band" илэрсэн нь дээрх ургамлууд удам төрлийн хувьд ойролцоо байх магадлалтай бол I.flavisimma-г 500, 600 bp-т 2 "band" илэрсэн нь удам төрлийн хувьд бусдаас ялгаатайг илтгэж, ITS бүс нь дор хаяж 2 удаа давтагдан орсон байгааг харуулж байна. Ургамлын филогенез холбоог илрүүлэхэд түгээмэл хэрэглэдэг юниверсаль праймер болох $\operatorname{trnL}, \operatorname{trnF}-\Gamma$ хэрэглэхэд I.ventricosa-c бусад дээжний
ДНХ амжилттайгаар олширч ойролцоогоор 800 bp-т "band" илэрсэн нь тэдгээр ургамлууд бүгд trnL-trnF бүсийг бүрэн агуулсан байгааг харуулж байна.

Цахилдагны зүйл ургамлуудын хлоропластын ДНХ-н нуклеотидын дараалал $(\mathrm{NCBI})$ дээр үндэслэн филогенезийн модыг байгуулахад цахилдагны зарим зүйл ургамлуудаас I.sanguinea ба I.sibirica удам төрлийн хувьд хамгийн ойр холбогдож байгаа бол, I.rutenica ба I.uniflora филогенезийн хувьд ойролцоо болох нь харагдаж байна. Мөн I.tenuifolia, I.ventricosa, I.halophila зүйлүүд удам төрлийн нэг мөчирт холбогдож байна. Харин I.tigrida бусад зүйлээс хлоропластын нуклеотидын дарааллын хувьд харьцангуй хол болох нь филогенез модноос харагдаж байна.

\section{Талархал}

Энэхүү судалгааны ажлыг Монгол улсын ШУА, ШУТСангаас санхүүжүүлсэн “Молекул биологийн аргаар зарим эмийн ургамлын филогенетик холбоог илрүүлэх” грант төслийн (15ББ10АГ109) хүрээнд хийж гүйцэтгэв. 


\section{Аиигласан бүтээлийн жагсаалт}

1. Зүмбэрэлмаа Д., 2007, Хоёр зүйл цахилдагийн ангилалзүйн онилог, Шинжлэх Ухаан Академийн Мэдээ, 2: х48-54

2. Грубов В.И., 2008, “Монголын гуурст ургамал таних бичиг”(зургийн хамт), УБ. $x 81-84$

3. Urgamal M., Oyuntsetseg B., Nyambayar D., Dulamsuren Ch., 2014, "Conspectus of the vascular plants of Mongolia", UB. $x 44$

4. Lkhagvasuren S, Enkhtuya L, Tuya B, Mizukami H. Studies on the short DNA sequences (PS-ID sequence) of some medicinal plants. 2002 Proceedings of Mongolian Academy of Sciences 2: 45-49.

5. Lkhagvasuren S, Hampp R, Arkka M, Enkhtuya L, Sanchir Ch, Zumberelmaa D. Phylogenetic relationships of Iris species based on DNA sequences. 2004 Proceedings of Institute of Botany 15: 135-142.

6. Lkhagvasuren S, Purevsuren G, Oyun Z, Otgonbaatar U, Narantsetseg, Khishgee D. The prognosis of medicinal compounds of Iris species based on phylogeny relationship chloroplast DNA sequences. 2006 Proceedings of Mongolian Academy of Sciences 2: 72-75.

7. Оюунбилэг Ю., Ганбат Б., 2013, Нарийн навчит изахилдагийн (Iris tenuifolia Pall.) зигот үр хөврөлөөс in vitro өсгөвөр эхлҮүлсэн нь. Биологийн хүрээлэнгийн эрдэм иинжилгээний бүтээл, 29: $x 82-88$

8. Pierre Taberlet, Ludovic Gielly, Guy Pautou, Jean Bouvet. Universal primers for amplification of three non-coding regions of chloroplast. 1991 Plant Mol. Biol. 17(5): 11051109.

9. Irina Makarevitch, Kseniya Golovnina, Svetlana Scherbik, Alexander Blinov. Phylogenetic relationships of the Siberian Iris species inferred from noncoding chloroplast DNA sequences. 2003 Int. J. Plant Sci. 164(2): 229-237. 


\title{
THE PHYLOGENETIC RELATIONSHIP OF SOME IRIS SPECIES
}

\author{
Kh. Altanzul, Yu. Oyunbileg \\ Laboratory of Plant Biotechnology, \\ Institute of General and Experimental Biology, MAS
}

The phylogenetic relationship of eight Iris species (I.flavisimma, I.ventricosa, I.bungei, I.kaempferi, I.tenuifolia, I.lactea, I.tigrida, I.dichotoma) were studied by PCR using six specific primers (S-523, Z1204R, trnL, trnF and ITS1, ITS4). All species except I.ventricosa were identified when using S-523, Z1204R and trnL, trnF primers and the DNA fragment size ranged between 500 to $600 \mathrm{bp}$ and $800 \mathrm{bp}$, respectively. Primers ITS1 and ITS4 produced double bands in about 500 and $1500 \mathrm{bp}$ to I.bungei, I.kaempferi, and I.lactea species. On the phylogenetic tree, some iris species have close relations based on chloroplastic DNA sequences. The closest relationships showed between I.sanguinea and I.sibirica, I.rutenica and I.uniflora. Also I.tenuifolia, I.ventricosa and I.halophila located on one branch of phylogenetic tree. 